\title{
The Role of Early Mobilization on Wound Healing After Sectio Caesarea
}

\author{
Adinda Putri Sari Dewi', Nuning Juni Setianingsih', Siti Maesaroh', Umi Sulasih', Wulan \\ Rahmadhani $^{1^{\star}}$, Eka Novyriana ${ }^{1}$ \\ ${ }^{1}$ Faculty of Health, Univeritas Muhammadiyah Gombong \\ *Corresponding author : wulannnnn02@gmail.com
}

\section{ARTICLE INFO}

Article history

Received 31/12/2021

Revised 18/01/2022

Accepted 20/01/2022

Keywords

Sectio caesarea

Early mobilization

Wound healing

Postpartum

\begin{abstract}
Background: Sectio Caesarea (SC) is a surgical procedure performed by giving an incision on the abdominal wall and uterus with the aim of assisting the delivery process by removing the fetus from the mother's womb. The delivery rate in 2018 was $17.6 \%$ of the total number of deliveries in Indonesia. In 2020 there were $67 \%$ of post SC patients whose impact from long wound healing when viewed from the health impact that would be caused was the risk of infection. Carrying out early mobilization can help the wound healing process.Objective: the purpose of this study was to analyze and summarize the results of one study with another regarding early mobilization of surgical wound healing in sectio cesarean cases.Method: literature reviewed was use in this research. Data from PubMed and google scholar conducted in this literature review. Result: the implementation of early mobilization is very effective in post-cesarean recovery. Conclusion: From all the journals that have been reviewed and taken as literature, it was found that all research variables are related, so it can be concluded that there is a relationship between early mobilization of post sectio caesarea and the wound healing process.
\end{abstract}

\section{Introduction}

Sectio caesarea is a medical action that is needed to help labor with certain indications, both due to maternal health problems and fetal conditions. Sectio caesarean delivery is carried out when normal labor cannot be done but also at the request of the patient himself or the handled doker [1]. According to the Word Health Organization the number of sectio caesarea increases in developing countries reaching $5-15 \%$ per country, one of the developing countries is Indonesia. Based on the results of basic health research in 2018 showed the prevalence of childbirth in Indonesia with vaginal action reached $81.5 \%$ and sectio caesarea action reached $17.6 \%$. Sectio caesrea delivery with the highest proportion in Indonesia, namely in DKI Jakarta there is $31.1 \%$ and sectio caesarea action is lowest in Papua with a total of $6.7 \%$. For the west Java region, the delivery of sectio caesarea reached $15.5 \%$ [2]. One of the direct causes of marternal death in Indonesia is related to persalina and postpartum, namely direct causes of bleeding (27.3\%), eclampsia (24.\%), and infection $(7.3 \%)$ [3]. while indirect causes of maternal death include chronic lack of energy in pregnancy (6.6\%), and anemia in pregnancy (40\%) [4]. Childbirth with sectio caesarea has a 25 times greater risk of death compared to vaginal delivery, although sectio caesarea is the best alternative for mothers who have a high risk in the delivery process or to save the life of the mother or fetus [5]. The act of delivery sectio caesarea causes a sore that must be considered the degree of healing of the wound because of the high risk of infection, rupture uteri, and bleeding. One that plays a role in wound healing is nutrition, age, obesity, medication, and early mobilization that are believed and proven to improve the wound healing process [6]. If early mobilization is not done as soon as possible will be able to cause complications, namely thrombosis and thromboemmboy [7].

Early mobilization in post sectio caesarea patients is an important aspect in recovery, early mobilization is carried out depending on the absence of labor and postpartum complications. In post 
SC mothers are allowed to get out of bed at most 24-48 hours after giving birth to be recommended to start early mobilization with right tilt or left tilt, sitting then walking [8]. Early mobilization is one of the factors that support the wound healing process, preventing thrombosis and thromboemboli, the potential for decreased functional ability, infection and so on. In wound healing early mobilization needs to be done gradually to speed up the wound healing process or post-surgical wound recovery, and can improve lung function, minimize the risk of blood clot formation, and also allow the client full physiological function [8].

The stage of postoperative mobilization is the first 6 hours after surgery the patient must be baring and can only move the arms, hands, move the tips of the toes, and rotate the tips of the toes and rotate the ankles, lift heels, tense the calf muscles and bend and shift the legs. Asien is required to tilt left and right for 6-10 hours to prevent thrombosis and thromboemboli. After 24 hours the patient is encouraged to learn to sit, then continue with walking [9]. Independence of early mobilization is important, otherwise there will be some impacts that arise such as: increased body temperature, abnormal bleeding, thrombosis, bad involution, blocked blood flow, and increased intensity of pain [10]. Early mobilization that is not conducted by post SC is a longer stay, which is more than four days and the wound healing process becomes slow [9]. Another impact caused by delays in early mobilization is the occurrence of infection. This is in accordance with research conducted [11] got signs of infection in the surrounding wound area because it did not mobilize early post SC. Based on the results of research conducted by [12] there were 7 respondents (16.7\%) with non-dry wounds and there were 4 respondents $(9.5 \%)$ who noticed an increase in pain, palpable warmth and redness in the wound did not blend due to not doing early mobilization post SC

This is supported in the 2018 study with the title of the relationship of early mobilization post sectio caesarea with wound healing with research methods using analititic surveys with a prosexial approach with a total of 40 respondents the majority of respondents who are not good post SC wound healing is respondents who do not do early mobilization as many as 13 respondents (32.5\%) the majority are good in wound healing [13]. Post SC is a respondent by doing early mobilization as many as 14 respondents (35\%) results in this study said there is a relationship of early mobilization post sectio caesarea with wound healing surgery [11].

Based on phenomena from the background above and from previous research data, therefore it is necessary to identify how early mobilization relationships in wound healing in post SC mothers by analyzing from several research journals related to the topic with literature review analysis. With the source of several research journals, researchers are interested in conducting research using Literature Review with the title of the role of early mobilization in the wound healing process in post SC mothers.

\section{Materials and Method}

The method used is literature review. In the first stage, it begins by searching for articles using PubMed and Google Scholar. The keywords used in the search for articles are sectio caesarea, sc, early mobilization, wound healing, post-partum mother. The articles obtained will be reviewed to obtain articles that meet the predetermined criteria. The inclusion criteria in the search for articles were chosen based on the year of publication, namely the range of 2017-2021 where the subject post Sectio Caesarea mothers. The exclusion criteria at the time of the article search were selected according to the research variables, the variables were not compared with other variables. The search was carried out according to keywords and found articles that were close to 30 the selection of subsequent articles was arried out based on inclusion and exclusion criteria which finally resulted in 20 articles being reviewed.

The journals that have been found are then specified according to the inclusion criteria and exclusion criteria, namely IC1: journal published, IC2: journal published in 2017-2021, IC3: type of quantitative research, IC4: non-duplicate journal published on Google scholar. After conforming to IC1-IC4, only 15 articles remained. Then IC5 was selected based on the compatibility of article titles and abstracts with the aim of this literature review, which was to have the main content investigating early mobilization of surgical wound healing in cases of caesarean section and only 5 journals were selected to be analysed. 
The strategy in searching the literature is attached to

Figure 1

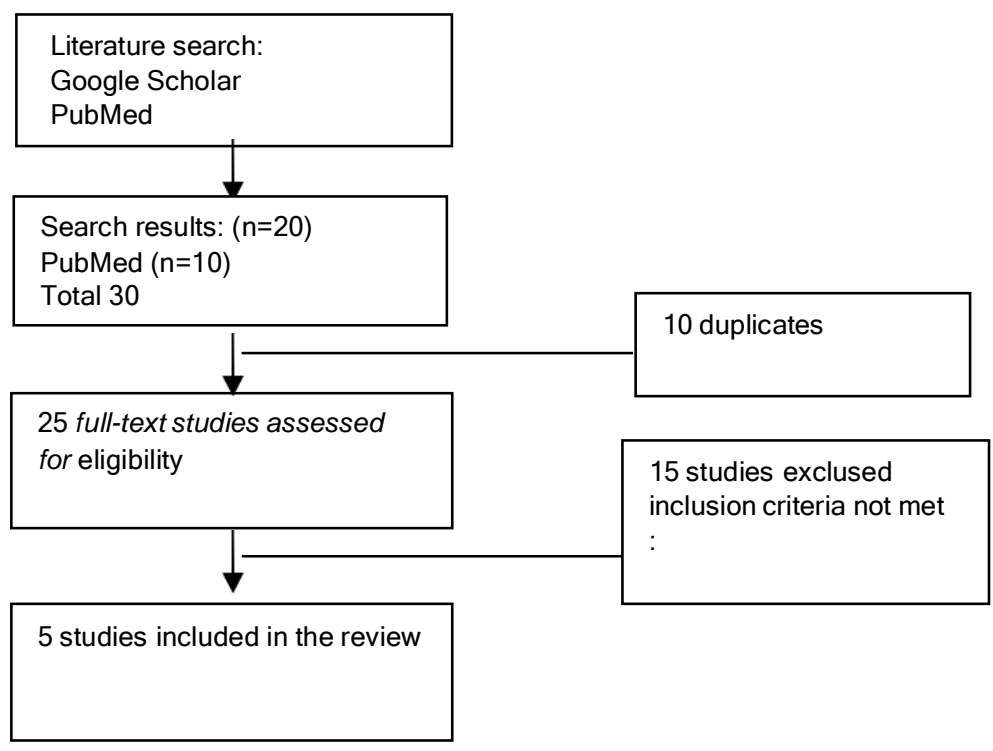

Figure 1. Flow of literature review

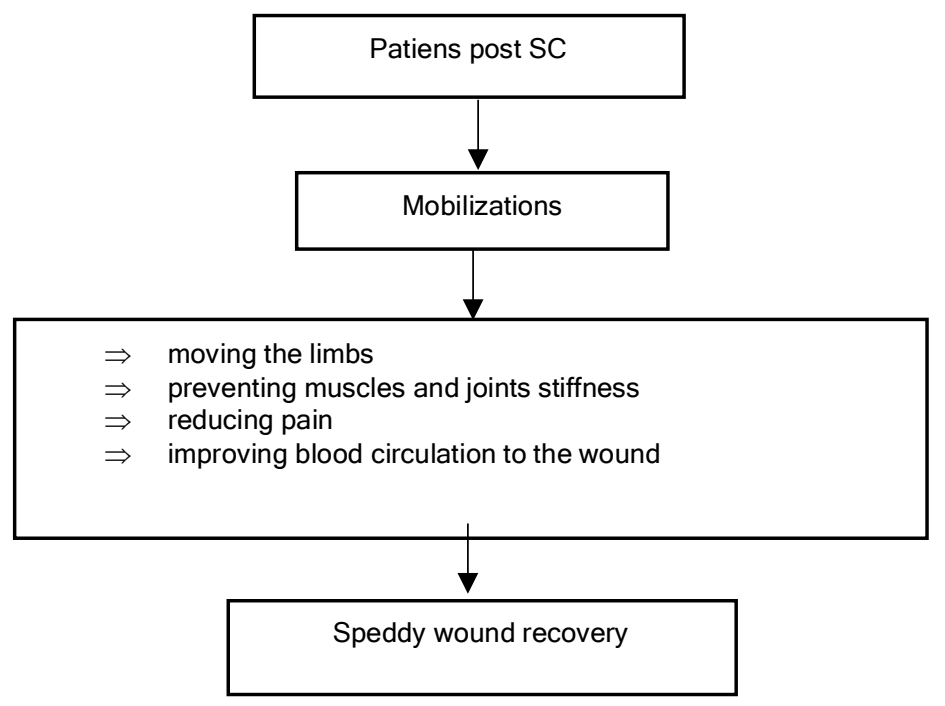

(Figure2. Wound recovery mechanism) 


\section{Results and Discussion}

This section may be divided by subheadings. It should provide a concise and precise description of the experimental results, their interpretation as well as the experimental conclusions that can be drawn.

\subsection{Results}

The authors conducted an exploration of the journal through a journal database based on the conformity of criteria that have been defined and keywords that have been established, namely the role of early mobilization on wound healing after sectio caesarea

Table 1. Literature review results

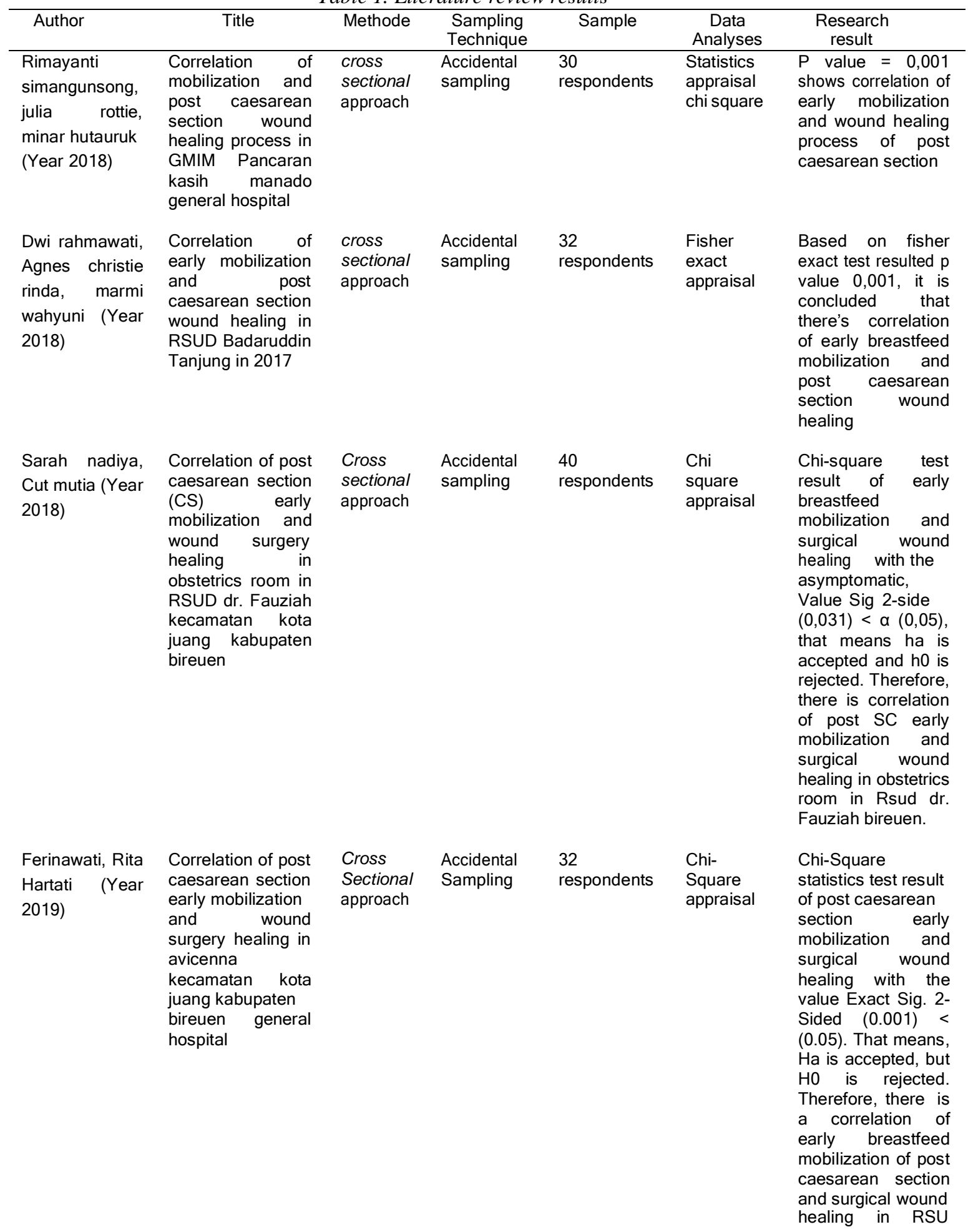




$\begin{array}{ll}\text { Anindhita } & \begin{array}{l}\text { Correlation of } \\ \text { early mobilization }\end{array} \\ \text { yudha } & \text { and healing of } \\ \text { Anyaningtyas, } & \text { sutures in post- } \\ \text { rahmawati } & \text { partum mothers } \\ \text { (Year 2020) } & \text { after caesarean }\end{array}$

$\begin{array}{llll}\begin{array}{l}\text { cross } \\ \text { sectional } \\ \text { approach }\end{array} & \begin{array}{l}\text { Total } \\ \text { sampling }\end{array} & \begin{array}{l}49 \\ \text { respondents }\end{array} & \begin{array}{l}\text { Chi square } \\ \text { appraisal }\end{array} \\ & & & \\ & & \\ & \end{array}$
$\rho$ value is 0,000 means $\rho<0.05$ by correlation coefficient of 0.854 , classified as very strong category $(0.80-1.00)$ it is concluded that there is significant correlation of early breasfeed mobilization and healing of sutures in post-partum mothers post caesarean section in pku muhammadiyah hospital karanganyar.

\subsection{Discussion}

Based on the results of the literature review that has been presented, it is known that carrying out early mobilization is very effective in post-caesarean recovery [12]. Many patients are reluctant to do early mobilization because they do not know the benefits of carrying out early mobilization. Patients also feel that they are still weak and still feel the pain so that they think that early mobilization can be done after recovering [14]. Early mobilization is known to be one of the factors associated with post-SC wound recovery. One of the benefits of early mobilization is that it can improve blood circulation. Smooth blood circulation is very helpful in the wound healing process, because when blood flows in the body it contains substances needed for wound healing such as oxygen, medicines, nutrition, etc [15].

Post-sectio caesarea mothers are advised to mobilize, but in mothers who experience sectio caesarea it is difficult to carry out mobilization because the mother feels tired and sick. One of the causes is the patient's ignorance regarding mobilization, for that health education about maximum mobilization is carried out. Mothers who experience sectio caesarea sometimes understand in the implementation of mobilization, but mothers do not understand what the benefits of mobilization [16]. Mobilization is a basic human need needed by individuals to carry out daily activities in the form of joint movements, attitudes, gait, exercise and activity skills [17]. Post-sectio caesarea mobilization can be done after the first 24-48 hours post-surgery. Mobilization aims to improve wound healing, improve circulation, prevent venous static, support optimal respiratory function, improve digestive function, reduce postoperative complications to restore patient function as much as possible as before surgery, maintain the patient's self-concept and prepare the patient to go home [18]. If mobilization is not carried out in post-sectio caesarea patients it will cause physiological and psychological harm. Physiological hazards affect normal metabolic function, lower metabolic rate, interfere with the metabolism of carbohydrates, fats and proteins cause imbalance of electrolyte fluids and calcium and can cause gastrointestinal disorders such as appetite and peristaltic decrease with contisipasi and impaction [19]. Mobilization can also speed up the wound healing process, by mobilizing the mother to feel healthier, stronger and can reduce pain thus the mother gains strength, accelerates healing, bowel and bladder function better, stimulates intestinal peristaltik back to normal and mobilization also helps speed up the organs of the body to work as before [20].

Many factors affect wound healing, but the careful execution of wounds is the most important part in controlling the occurrence of complications in postoperative wounds. One of the complications that are often found in hospitals is infection. Surgical wound infection is an infection that can be caused by several factors, including early mobilization of post SC [21] Some of the results of previous research conducted by [22] on the relationship of early mobilization of post SC with surgical wound healing with the number of patients 45 post-caesarean section mothers obtained results of $58.3 \%$ who did early mobilization of the wound healing process quickly and $81.8 \%$ who did not do early mobilization of the wound healing process slowly [18] found a difference in comfort between post- 
natal caesarean patients who made early mobilization and those who were late to mobilize [23]. Early mobilization can be an effort to maintain independence as early as possible so that patients can move their bodies or retrain muscles and joints after surgery, refresh their mind and reduce the negative impacts of psychological burdens which of course affect physical recovery in maintaining physiological function [24]. Early mobilization of post-surgery caesarean section patients is a nonpharmacological therapy that can be done for the patient's speedy recovery process. When mobilization is carried out properly, the effect is that the patients feel stronger and healthier [25]

It is highly recommended to apply post-SC early mobilization, beside speedy wound recovery, it can also reduce the length of time in hospital and can help reduce psychological stress that may arise [26]. Early mobilization of caesarean section in postpartum mothers is a movement or changing posture made by the mother a few hours after giving birth. The purpose of the mother's initial activities after caesarean section is to help speedy recovery and gradually return to the previous activity stage to prevent complications. Early ambulation will reduce muscle and joint stiffness, relieve pain, ensure smooth blood circulation, improve body metabolism regulation, restore the physiological work of vital organs, and hasten wound healing. On the other hand, moving the body or retraining muscles and joints after surgery will refresh the mind and reduce the negative impact of the psychological burden which will certainly have a good impact on physical recovery [27]. Early mobilization can shorten the recovery period and reach pre-surgery stages. This will definitely reduce hospital stays, reduce treatment costs, and reduce psychological stress [28]. If the mother does not move early, the first effect is that the body temperature rises due to poor uterine involution, therefore the remaining blood cannot be expelled and causes infection. The second is abnormal bleeding, because the early active uterus contracts well and hardens the uterine fundus, so the risk of abnormal bleeding can be avoided because the open blood vessels formed by contraction are narrowed, placenta, to the uterus. Contractions are disrupted [28]. As many as 5 articles indicated that early mobilization had an impact on caesarean section wound healing with a shorter healing time and good wound conditions than respondents without early [8] These results are in line with the research conducted [12] in the mother with postoperative SC and given early ambulation of acts at the Aura Syifa hospital in Kediri showed that wound healing mostly occurred on the third day. Like wise research conducted [16] also proved that as many as 15 respondents who made early mobilization regularly experienced a quick post SC recovery (65\%).

During the healing process, blood vessel that supply blood to the wound will experience blood clotting and thrombosits will gather in the wound area to stop the bleeding by forming fibrin thread tissues (fibrin matrix), this fibrin will then form cell repairing stuctures [1]. Then the damaged tissues secrete histamine that stimulates capillary vasodilation in the wound area and produced serum and white blood cells. Mobilization causes improvement of circulation, making deep breath and restimulating normal gastrointestinal function, push to move lower legs as soon as possible in 6 hours [12].

\section{Conclusion}

From all the journals that have been reviewed and taken as literature, it is found that all research variables are related, so it can be concluded that there is a relation between early mobilization of post caesarean section and hasten wound healing. The implementation of early mobility measures in patients with caesarean section surgery can increase the speed of wound healing and also good condition of the wound.

\section{Declaration}

Acknowledgments: The author would express gratitude to who help and participation in this research.

Conflicts of Interest: The authors declared that there is no conflicts of interest in this research. 


\section{References}

[1] N. F. A. M. Machmudah, "Penurunan Nyeri Pasien Post Sectio Caesarea Menggunakan Terapi Teknik Relaksasi Benson," Ners Muda, vol. 2, no. 2, 2021.

[2] A. M. A. C. S. Styaningsih, D. I. Budiono, "Patients Preferences And Experiences In Choosing The Model Of Normal Labor Care," Indones. Midwifery Heal, vol. 5, no. 2, 2021.

[3] W. Rahmadhani, "The Affecting Factors of Implementation of Expanding Maternal and Neonatal Survival Program by the Ministry of Health of the Republic of Indonesia in Determining Midwifery in Kebumen, Central Java, Indonesia," 2021, doi: 10.4108/eai.18-112020.2311621.

[4] A. S. H. I. B. G. S. Putra, I. M. Wandia, "Indikasi Tindakan Sectio Caesarea Di Rsud Sanjiwani Gianyar," J. Amj (Aesculapius Med. Journal), vol. 1, no. 1, pp. 63-68, 2021.

[5] D. Nanda, "Faktor-Faktor Yang Mempengaruhi Penyembuhan Luka Post Operasi Sectio Caesarea Di Rsud Dr. H. Bob Bazar, Skm Tahun 2021," J. Kesehat., vol. 31, 2021.

[6] W. Rahmadhani and W. Laohasiriwong, "Gender of baby and postpartum depression among adolescent mothers in central Java, Indonesia," Int. J. Child Adolesc. Heal., vol. 13, no. 1 PG43-49, pp. 43-49, 2020, [Online]. Available: https://ezproxy.deakin.edu.au/login?url=http://search.ebscohost.com/login.aspx?direct=true \&AuthType=ip, sso\&db=ccm\&AN=145919839\&site=ehost-live\&scope=site NS -

[7] H. M. S. A. H. Yulianti, "Faktor-Faktor Yang Mempengaruhi Proses Penyembuhan Luka Post Sectio Caesarea," J. Ilmu Kesehat., vol. 6, no. 2, 2018.

[8] A. F. W. Indanah, S. Karyati, Q. A. Aulia, "Hubungan Status Paritas Dan Mobilisasi Dini Dengan Kemandirian Ibu Post Sectio Caesaria," J. Kebidanan, vol. 6, no. 1, pp. 660-665, 2021.

[9] A. L. A. R. Ananda, A. Inayati, "Penerapan Mobilisasi Dini Terhadap Proses Penyembuhan Luka Pada Pasien Dengan Post Operasi Appendiktomi Di Kota Metro," J. Cendekia Muda, vol. 1, pp. 436-444, 2021.

[10] W. Rahmadhani, "Knowledge Of Postpartum Mothers On Postpartum Care In Healthcare Centers In Kebumen," J. IIm. Kesehat. Keperawatan, vol. 16, no. 1, p. 28, 2020, doi: 10.26753/jikk.v16i1.379.

[11] S. S. A. A. N. Agustina, "Pengetahuan Dan Sikap Anak Tentang Mobilisasi Dini," J. IIm. Keperawatan IMELDA, vol. 4, no. 1, pp. 10-21, 2020.

[12] A. S. P. D. J. M. S. Singh, M. K. Nutan, "Effectiveness Of Early Ambulation On Post-Operative Post Operative Recovery Among Caesarean Mothers," Internatioanl J. Sci, vol. 12, no. 6, 2020.

[13] E. Novyriana, W. Rahmadhani, and P. Chamroen, "Mid-upper arm circumference (MUAC) for evaluation of anemia cases among pregnant women in Gombong, Kebumen, Central Java Indonesia.," Int. Public Heal. J., vol. 13, no. 1, 2021.

[14] Yulisetyaningrum, "Hubungan Mobilisasi Dini Dengan Kesembuhan Luka Pada Pasien Pasca Laparatomy Di Rsud Dr. Loekmonohadi Kudus," Urecol, vol. 1, no. 2, 2021.

[15] F. F. A. R. Hartati, "Hubungan Mobilisasi Dini Post Sectio Caesarea Dengan Penyembuhan Luka Operasi Di Rsu Avicenna Kecamatan Kota Juang Kabupaten Bireuen," J. Heal., vol. 5, no. 2, 2020.

[16] A. M. W. D. Rahmawati, A. C. Rinda, "Hubungan Mobilisasi Dini Dengan Penyembuhan Luka Post Sectio Caesarea Di Rumah Sakit Umum Daerah H. Badaruddin Tanjung Tahun 2017," J. Kesehat., vol. 9, no. 1, pp. 511-518, 2017.

[17] A. H. A. B. Santoso, "Penelitian Asli Pengaruh Mobilisasi Dini Terhadap Peristaltik Usus Pada Pasien Pasca Operasi Caesar Di Rsud Kota Kendari Uji Usia," Midwifery J., vol. 14, no. 3, 2019.

[18] A. M. H. R. Simangunsong, J. Rottie, "Hubungan Mobilisasi Dini Dengan Proses Penyembuhan Luka Post Sectio Caesarea Di Rsu Gmim Pancaran Kasih Manado," J. Keperawatan, vol. 6, no. 1, 2018.

[19] K. H. A. D. P. Sari, "Faktor Risiko Umur Ibu Yang Berisiko Tinggo Terhadap Kejadian Abortus," J. Kebidanan Kestra, vol. 1, no. 2, pp. 113-118, 2017.

[20] A. Y. C. A. A. Rahmawati, "Hubungan Mobilisasi Dini Dengan Penyembuhan Luka Jahitan Pada Ibu Nifas Post Operasi Sectio Caesarea," J. IIm. Kesehat., vol. 11, no. 1, 2020.

[21] S. N. A. C. Mutia, "Hubungan Mobilisasi Dini Post Sectio Caesarea ( Sc ) Dengan Penyembuhan Luka Operasi Di Ruang Kebidanan Rsud Dr . Fauziah Kecamatan Kota Juang 
Kabupaten Bireuen Mobilization Relationships In Post Sectio Caesarea ( Sc ) With Healing Of Operating," J. Heal. Technol., vol. 4, no. 2, 2018.

[22] Nurfitriani, "Pengetahuan Dan Motivasi Ibu Post Sectio Caesarea Dalam Mobilisasi Dini The Knowledge And Motivation Mothers Post Sectio Caesarea In Early Mobilization," J. Promosi Kesehat., vol. 2, no. 2, pp. 2528-2735, 2017.

[23] Risna, "Hubungan Umur Dan Pekerjaan Ibu Hamil Dengan Rencana Proses Persalinan Caesarea Di Rsud Hasan Sadikin Bandung Jawa Barat Tahun 2013," J. Kesehat., vol. 11, no. 1, 2013.

[24] M. Salamah, "Hubungan Mobilisasi Dini Dengan Pemulihan Luka Post Sectio Caesarea Di Rumah Sakit Panembahan Senopati Bantul," J. Kebidanan, vol. 2, no. 1, 2017.

[25] S. N. H. Saleh, "Analisis Pemberian Mobilisasi Dini Post Sectio Caesarea Dengan Proses Penyembuhan Luka Operasi Di Ruang Nifas Rumah Sakit Umum Daerah Kota Kota Mobagu," J. Kebidanan, vol. 4, no. 1, pp. 1-5, 2020.

[26] E. S. Roslianti, Y. Srinayanti, J. Kusumawaty, "The Description Of The Treatment Of Early Mobilization On The Mother Post Sectio Caesarea In Lotus li Blud Hospitals Banjar Year 2018," J. Stikes Muhammadiyah Ciamis," J. kebidanan, vol. 5, no. 1, 2018.

[27] A. M. M. Y. A. Mustikarani, W. T. Purnani, "Pengaruh Mobilisasi Dini Terhadap Penyembuhan Luka Post Sectio Caesarea Di Rs Aura Syifa Kabupaten Kediri," J. Kesehat., vol. 12, no. 1, pp. 56-62, 2019.

[28] H. A. A. Ardenny, "Pengaruh Mobilisasi Dini Terhadap Penyembuhan Luka Post Sectio Caesarea," J. Kebidanan, vol. 11, no. 1, pp. 109-115, 2017. 